\title{
Ostreid herpesvirus: A pathogen of oysters
}

\author{
Daniela Mandas ${ }^{1}$ and Fulvio Salati ${ }^{*}$ \\ ${ }^{1}$ Fish Diseases and Aquaculture Center, IZS of Sardinia, State Veterinary Institute Via Parigi s.n., 09170 Oristano, Italy
}

\begin{abstract}
Ostreid Herpesvirus-1 (OsHV-1), OsHV-1 $\mu$ var and other variants are herpesviruses causing heavy mortalities, with losses ranging from 50 to $100 \%$, on Pacific oyster (Crassostrea gigas), an important species worldwide cultured. Ostreid Herpesvirus- 1 is one of the top 50 largest viral genome; OsHV-1 $\mu$ var is a variant of the virus OsHV-1 showing a systematic deletion of $12 / 13$ base pairs sequence between ORF4 and ORF5. For the diagnosis of herpesvirus infection, traditional histopathological methods and biomolecular techniques have been developed, but, to confirm the disease, both methods should be used. This mini review reports some studies on the virus.
\end{abstract}

\section{Introduction}

Pacific oyster (Crassostrea gigas) is an important species worldwide cultured showing great production figures in many countries such as China, Japan, South Korea, U.S.A., Mexico, New Zealand, Australia, France, UK, Ireland, Spain, Italy, etc. However, oyster culture is periodically struck by heavy mortalities ranging from 50 to $100 \%$. Oyster culture industry is based on both supply of the spat from the wild and from hatchery, where most of the larvae are produced using a "mass spawning" technique. Problems with low salinity, disease, or other water quality associated problems may delay or inhibit spawning. There are several different methods used for oyster growing. The methods range from culture on the bottom, to suspension in "poches", baskets, etc., by rope and/or long-lines (Figure 1). Pacific cupped oysters will take from 18-30 months depending mainly on water temperature to reach a market size of 70-100 g live weight, $>75 \mathrm{~mm}$ shell length.

Losses of Pacific Oyster (C. gigas) have occurred globally for over 5 decades with heavy impact on oyster aquaculture. These losses generally denominated as Summer Mortality are typically prolonged and affect older reproductively mature animals during summer months [1]. In Europe, C. gigas was introduced to replace Crassostrea angulata, because significant summer mortalities have occurred since the late eighties [2-4]. The Pacific oyster may also be infected by different viruses; an irido-like virus has been reported infecting French Pacific oysters [5]. Although the Portuguese oyster, C. angulata, was highly

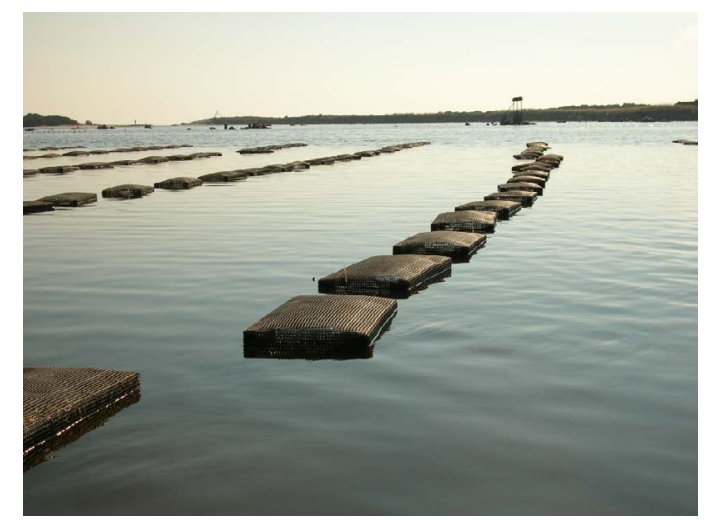

Figure 1. Oyster "poches” culture in S. Teodoro Lagoon (Italy). susceptible to this virus, C. gigas appeared resistant to this virus disease. In late 70ies and early 80ies, high mortalities (more that 50\%) of Pacific oyster larvae have been reported in commercial hatcheries from Washington State in USA [6].The cause of C. gigas summer mortalities remained unclear, but studies suggested a complex etiology in which environmental and physiological conditions of the host (age/weight and sexual maturation) were involved $[7,8]$.

Since 1992 sporadic high mortalities of larval C. gigas have been regularly observed in some commercial French hatcheries, occurring every year during summer in association with a herpes-like virus (Ostreid Herpesvirus 1: OsHV-1) [9,10]. In 2008 summer mortalities were reported at a much larger scale. The mortality events affected juvenile oysters and up to $100 \%$ mortalities were observed in a few weeks period between June and July. A new strain of OsHV-1 denominated $\mu$ var was consistently observed. Extensive mortalities were again observed in 2009 and from 2010 in all French coast and also in Ireland, Jersey and Italy.

\section{Ostreid Herpesvirus}

The Virus Study Group of the International Committee on Taxonomy of Viruses (ICTV) has recently established a new order, the Herpesvirales, which includes herpesviruses of mammals, birds, reptiles, amphibians, fish and bivalves. A carachteristic of Herpesvirales is the latent or inapparent infection that could be present in host cells, but without replication. Genetically, Herpesviridae (mammals), Alloherpesviridae (amphibians) and Malacoherpesviridae (bivalves) are very few correlated. There is an unique protein, a terminase sub-unit responsible for DNA packaging, that could be considered Herpesvirusspecific. Based on terminase gene's taxonomy-tree, the virus of oyster is a clade a part from the other Herpesvirus. In Figure 2 herpesviruses dataset and phylogenic tree from Waltzek, et al. are shown [11].

Correspondence to: Salati F, Fish Diseases and Aquaculture Center, IZS of Sardinia, State Veterinary Institute Via Parigi s.n., 09170 Oristano, Italy, Tel: 328-6256492; E-mail: fulviosal@hotmail.com

Key words: pacific oyster, crassostrea gigas, malacoherpesviridae, ostreavirus, ostreid herpesvirus-1, OsHV-1 $\mu$ var, infection

Received: April 14, 2017; Accepted: April 26, 2017; Published: April 29, 2017 


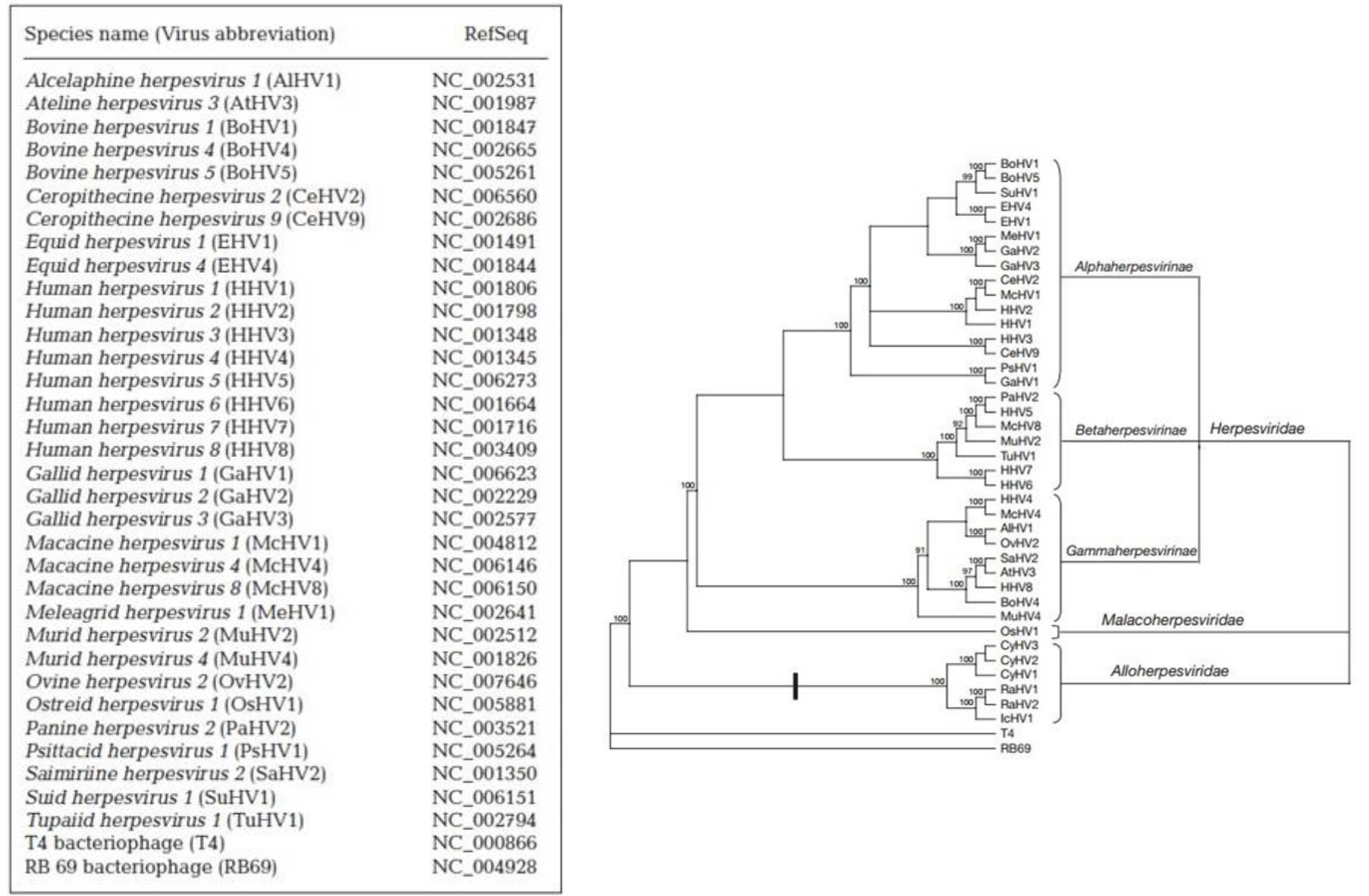

Figure 2. Herpesviruses dataset and phylogenic tree [11].

Malacoherpesviridae contains Ostreid Herpesvirus-1 (OsHV-1) as its sole member, in the genus Ostreavirus [12]. Ostreid Herpesvirus-1 is a virus which core contains a linear double-stranded DNA with an icosahedral capside [13]. The sequence has been deposited in 2005 by Davison, et al. [14] and it is at 27th ranking of the top 50 largest viral genome sequence list. The sequence of the OsHV-1 is deposited in GenBank (GenBank AY509253), lenght estimated of 207 kbp: Davison et al. showed that the genome is assembled by two regions UL $(167,843$ bp) and US (3370 bp), each flanked by inverted repeats TRL/IRL (7584 bp) and TRS/IRS (9774 bp), and separated by a X region of $1510 \mathrm{bp}$ [14].

\section{OsHV-1 $\mu$ var}

In the past decades, only Ostreid Herpesvirus 1 (reference type) and Ostreid Herpesvirus 1var were known; then other $\mathrm{C}$ region variants have been detected. In 2008 an emerging variant, OsHV-1 $\mu$ var was isolated [15]. OsHV-1 $\mu$ var, shows a deletion in position 178204-178404 of about 200 bp which probably compromises the protein codified by ORF5, and there is an insertion of $27 \mathrm{bp}$ not present in any published sequence (CCCACTGTGATATCATCGCAAATGAAT ). In particular, OsHV-1 $\mu$ var is a variant of the virus OsHV-1 of $529 \mathrm{bp}$ fragment length, which is defined on the basis of partial sequence data exhibiting a systematic deletion of 12/13 base pairs in TAC sequence between ORF4 and ORF5 in the posion 178547 at 178572 of the genome (GenBank \# HQ842610) in comparison with OsHV-1. Moreover, in some cases a deletion with only $10 \mathrm{bp}$ in the same position was also observed. Furthermore, recent genomic regions analysis revealed the presence of at least nine different genotypes, including two variants close to the OsHV-1 (reference type) $[16,17]$. In particular, phylogenetic analysis results highlight two distinct clusters with a different geographical, European and East Asian, genotypes distribution.

\section{Diagnosis}

Nowadays, since there are not cell cultures from oyster and/ or alternative cell culture, the viral isolation is not possible and there are no sensitive serological detection methods, but traditional histopathological methods and biomolecular techniques are used for the diagnosis of herpesvirus infection. However, to confirm the disease, both methods should be used.

Regarding the histopathological examination, what can be observed are the typical signs of a viral infection: connective tissue cells with pycnosis, nuclear changes (moon shaped), including nuclei hypertrophy with marginated chromatin, and large intranuclear acidophilic inclusion bodies (Cowdry type A inclusions) [10,1821]. Moreover, the observation by electron microscopy of capsids or nucleocapsids in the nucleus and virus particles in the cytoplasm or in cytoplasmic vesicles could only confirm the presence of a herpesviruslike and/or a viral disease [10,18-20,22-24].

On the other hands, both in situ hybridization (ISH) $[25,26]$ and PCR could be positive for the DNA of OsHV-1 and variants detection but not enough for the disease confirmation. To date, there are numerous different PCR methods available for the detection of OsHV-1, but specific and characteristic are the primers $\mathrm{C} 2$ and $\mathrm{C} 6$, which bracket a region of 709 bp (178181-178889) [27-29] (Figure 3 and 4). Some methods of PCR 


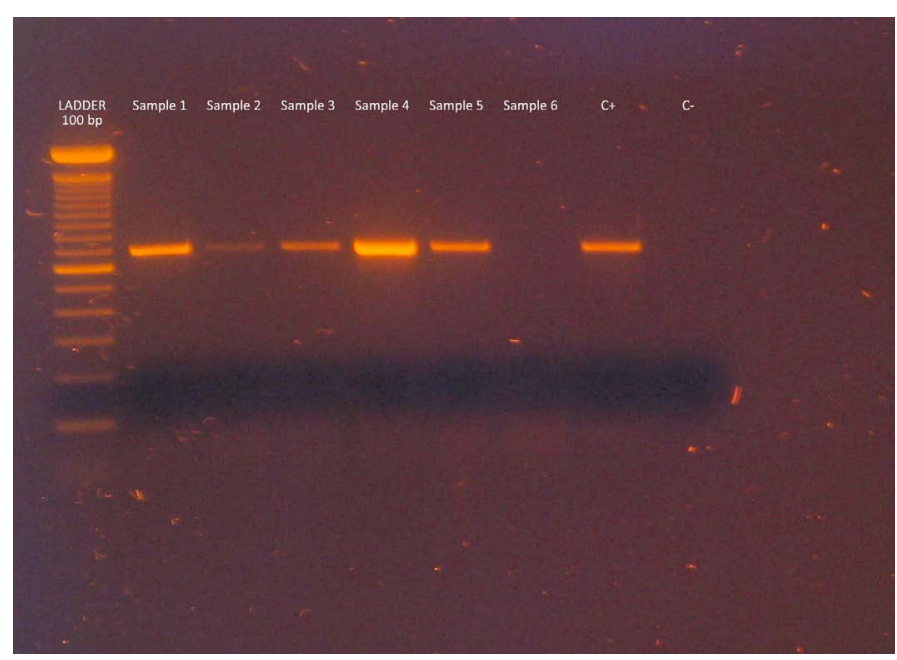

Figure 3. Example of OsHV-1 gel from diseased C. gigas. The gel shows the reference virus and virus-negative oyster tissue. Es. Samples line 1 to 5: positive; Sample line 6: negative; $\mathrm{C}+=$ reference OsHV-1; $\mathrm{C}$ - =negative.

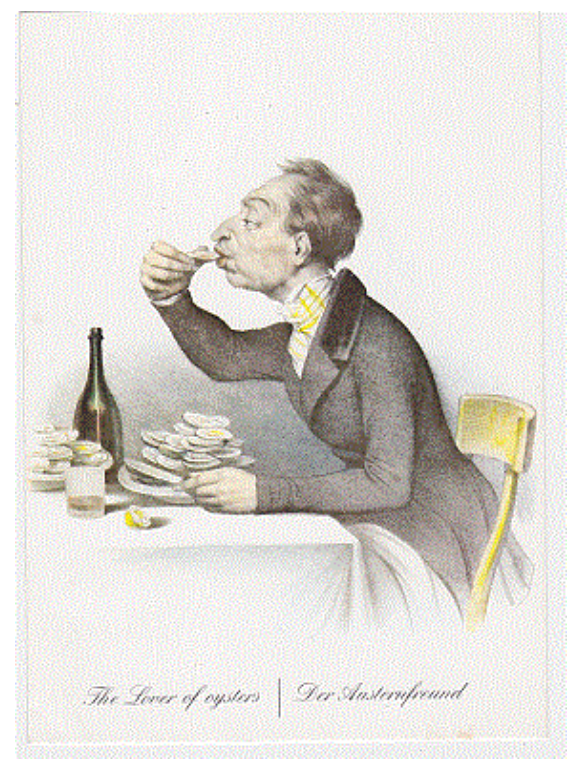

Figure 4. The lover of oysters

utilize a PCR where the DNA sequence is amplified by one primer pair, other methods use nested PCR with two amplification using two primer pairs: primer sets $\mathrm{C} 2-\mathrm{C} 4, \mathrm{C} 2-\mathrm{C} 6$ [28] and C2-C6 and CF-CR. The late should be used to clearly identify the OsHV-1 $\mu$ var strain from the reference strain by comparison with positive controls [30]. Furthermore, sometimes it is difficult to distinguish, on the electrophoresis gel, between the reference and the $\mu$ var; particularly, in case of double infection, the bands may overlap and form a broad band. Moreover, CF-CR primers could produce a ghost band from host DNA which has been identified by sequencing. The PCR may not be sensitive enough to detect virus at very low levels found in latent infections and, as a consequence, the Real-Time method using the CF-CR results to be more accurate to distinguish the strain. Therefore, some laboratories prefer to sequence the PCR product.

From 2008-2009, OsHV-1 $\mu$ var was detected in association with high mortality events in many European countries, while analysis conducted in samples associated to mortality events prior to 2008, between 1995 and 2007, did not detect the same virus [31,32]. Furthermore, OsHV-1 $\mu$ var was recently detected in Wadden sea [33] and in Adriatic sea [17].

\section{Virus infectivity}

Studies in vitro on virus stability and infectivity are very few. Ten pg $\mu \mathrm{l}-1$ of extracted viral DNA were experimentally detected for 1,9 and 16 day at 20,11 and $4^{\circ} \mathrm{C}$ respectively and, in a second experiment, $100 \mathrm{pg} \mu \mathrm{l}-1$ were detected after 51 days at each of the same temperatures [34]. However, the relationship between DNA detection in the PCR and infectivity is unknown. As a general rule of many aquatic animals viruses, considering also what observed in the field, the survival of OsHV is longer at lower temperatures.

OsHV virus, as other herpesviruses, could be present in host cells without replication, at latent or inapparent infection status and could be reactivated and recommences replication under a summ of environmental (such as water temperature, salinity, etc.) and host stressing conditions (i.e. age and sexual maturation of the host), etc. OsHV-1 was also detected in apparently healthy farmed oysters $[27,29]$ and, again, in healthy farmed C. gigas from the Gulf of California [35]; while, regarding the oysters in the wild, the presence of OsHV-1 was recently confirmed in European natural C. gigas [17].

Water is probably the most important natural route of trasmission of OsHV-1, since its DNA has been detected in the water around diseased Pacific oysters [36,37]. The experimental infection of Portuguese oyster, C. angulata, and Suminoe oyster, C. rivularis, has been performed by waterborne with extracted OsHV-1 or by cohabitation with infected C. gigas, respectively [38]. Furthermore, there are observations from both aquaculturists and researchers that the infection rate of young oysters results in higher mortality and morbidity than in older oysters, but infected adults may be the source of infection for larvae or spat, particularly if the oysters are in a stressing environment, e.g. high temperature $[22,32,34]$. Moreover, it is not confirmed if there is a vertical transmission other than horizontal one since the results were inconclusive [40].

Regarding the infectivity of OsHV(s) on marine molluscs, other than C. Gigas, there are few data. The first record of a herpes-like virus in a bivalve mollusc in the USA was that described by Farley, et al. [41] in C. virginica. However, herpes-like virus have been reported in some molluscs such as C. ariakensis/C. rivularis, C. hongkongensis, C. sikamea [29], C. gigantea [42], Ostrea edulis [9], Pecten maximus [43], Ruditapes decussatus [38,44] R. Philippinarum [38,43,44], Saccostrea glomerata [45] and Tiostrea chilensis [49]. In many cases, the identification of the virus was based on electronic microscopy and histopathological examinations of infected tissues consistent with the characteristics of that of herpesviruses, while before 2005 biomolecular examination was not always performed. Recently, Lopez-Sanmartin et al. (2016) demonstrated that O. edulis could be infected by OsHV-1 $\mu v a r$ by intramuscular injection.

In conclusion, Pacific oyster (C. gigas) infection by OsHV-1, OsHV$1 \mu \mathrm{var}$ and other variants is cause of mortalities damaging aquaculture productions. There are various tools for diagnosis ranging from histopathological methods to biomolecular techniques such as in situ hybridization (ISH) and PCR and PCR Real-Time. However, as stated before, to confirm the disease, both methods should be used. Despite of diagnosis progresses, the problem on the field is currently unsolved: one measure now applied in the hatcheries is to produce virus free spats using parents checked to be virus free and kept in controlled water. 
However, when the oysters are put in the sea, the disease can appear again, probably because the virus can be in the environment. Another way to fight the disease is the production of polyploid oysters: since better survival was recorded using triploid oyster [47], because they commonly have lower gonadal activity, are less fertile than diploids [48] and spare energy to more effectively fight the viral disease. Recently together to polyploid production, studies on genetic selection with the purpose of obtaining a more genetically resistent oysters strain/family have started [49,50-52]. Moreover, studies on oyster immune response to Ostreid Herpesviruses and newly appeared pathogenic bacteria, such as Vibrio aestuarianus, [53,54] are now developing [55-67].

\section{References}

1. EFSA (2010) Scientific Opinion on the increased mortality events in Pacific oysters, Crassostrea gigas. EFSA Journal8:1894-1956.

2. Maurer D, Comps M, His E (1986) Caractéristiques des mortalités estivales de l'huître Crassostrea gigas dans le bassin d'Arcachon. Haliotis 15:309-317.

3. Bodoy A, Garnier J, Razet D, Geairon P (1990) Mass mortalities of oysters (Crassostrea gigas) during spring 1988 in the bay of Marennes-Oléron, related to environmental conditions. ICES11: 1-23.

4. Goulletquer P, Soletchnik P, Le Moine O, Razet D, Geairon P, et al. (1998). Summer mortality of the Pacific cupped oyster Crassostrea gigas in the bay of Marrennes-Oleron (France). ICESpp: 14-21.

5. Comps M, Bonami JR (1977) [Viral infection associated with mortality in the oyster Crassostrea gigas Thunberg]. C R Acad Sci Hebd Seances Acad Sci D 285: 1139-1140. [Crossref]

6. Elston RA (1979) Virus-like particles associated with lesions in larval Pacific oysters (C. gigas). J Inv Pathol33: 71-74.

7. Barbosa-Solomieu V, Dégremont L, Vázquez-Juárez R, Ascencio-Valle F, Boudry $\mathrm{P}$, et al. (2005) Ostreid herpesvirus 1 (OsHV-1) detection among three successive generations of Pacific oysters (Crassostrea gigas). Virus Res 107: 47-56.[Crossref]

8. Soletchnik P, Ropert M, Mazurie J, Fleury PG, Le Coz F (2007) Relationships between oyster mortality patterns and environmental data from monitoring databases along the coasts of France. Aquaculture 271:384-400.

9. Comps M, Cochennec N (1993) A herpes-like virus from the European oyster Ostrea edulis L. J Invertebr Pathol 62: 201-203.

10. Renault T, Cochennec N, Le Deuff RM, Chollet B (1994) Herpes-like virus infecting Japanese oyster (Crassostrea gigas) spat. Bull Eur Ass Fish Pathol 14:64-68.

11. Waltzek TB, Kelley GO, Alfaro ME, Kurobe T, Davison AJ, et al. (2009) Phylogenetic relationships in the family Alloherpesviridae. Dis Aquat Organ 84: 179-194.[Crossref]

12. Davison AJ, Eberle R, Ehlers B, Hayward GS, McGeoch DJ, et al. (2009) The order Herpesvirales. Arch Virol 154: 171-177.[Crossref]

13. Minson AC, Davison A, Eberle R, Desrosiers RC, Fleckenstein B, et al. (2000). Family Herpesviridae. In Virus Taxonomy.Seventh Report of the International Committee on Taxonomy of Viruses, pp. 203-225.

14. Davison AJ, Trus BL, Cheng N, Steven AC, Watson MS, et al. (2005) A novel class of herpesvirus with bivalve hosts. J Gen Virol 86: 41-53.[Crossref]

15. Segarra A, Pépin J-F, Arzul I, Morga B, Faury N, et al. (2010) Detection and description of a particular Ostreid herpesvirus 1 genotype associated with massive mortality outbreaks of Pacific oysters, Crassostrea gigas, in France in 2008. Virus Res 153:92-99.

16. Martenot C, Fourour S, Oden E, Jouaux A, Travaillé E, et al. (2012) Detection of the OsHV-1 $\mu$ Var in the Pacific oyster Crassostrea gigas before 2008 in France and description of two new microvariants of the Ostreid Herpesvirus 1 (OsHV-1). Aquaculture 338-341:293-296.

17. Burioli EA, Prearo M, Riina MV, Bona MC, Fioravanti ML, et al. (2016) Ostreid herpesvirus type 1 genomic diversity in wild populations of Pacific oyster Crassostrea gigas from Italian coasts. J Invertebr Pathol 137: 71-83.[Crossref]

18. Burge CA, Griffin FJ, Friedman CS (2006) Mortality and herpesvirus infections of the Pacific oyster Crassostrea gigas in Tomales Bay, California, USA. Dis Aquat Organ 72: 31-43.[Crossref]

19. Da Silva PM, Renault T, Fuentes J, Villalba A (2008) Herpesvirus infection in European flat oysters Ostrea edulis obtained from brood stocks of various geographic origins and grown in Galicia (NW Spain). Dis Aq Org 78:181-188.
20. Friedman CS, Estes RM, Stokes NA, Burge CA, Hargove JS, et al. (2005) Herpes virus in juvenile Pacific oysters Crassostrea gigas from Tomales Bay, California, coincides with summer mortality episodes. Dis Aq Org 63:33-41.

21. Vásquez-Yeomans R, García-Ortega M, Cáceres-Martínez J (2010) Gill erosion and herpesvirus in Crassostrea gigas cultured in Baja California, Mexico. Dis Aquat Organ 89: 137-144.[Crossref]

22. Le Deuff RM, Renault T, Gerard A (1996) Effects of temperature on herpes-like virus detection among hatchery-reared larval Pacific oyster Crassostrea gigas. Dis Aquat Org24: 149-157.

23. Nicolas JL, Comps M, Cochennec N (1992) Herpes-like virus infecting Pacific-oyster larvae, Crassostrea gigas. Bull Eur Ass Fish Pathol 12:11-13.

24. Renault T, Le Deuff RM, Chollet B, Cochennec N, Gérard A (2000) Concomitant herpes-like virus infections in hatchery-reared larvae and nursery-cultured spat Crassostrea gigas and Ostrea edulis. Dis Aquat Organ 42: 173-183.[Crossref]

25. Martenot C, Segarra A, Baillon L, Faury N, Houssin M, et al. (2016) In situ localization and tissue distribution of ostreid herpesvirus 1 proteins in infected Pacific oyster, Crassostrea gigas. J Inv Path 136:124-135.

26. Lopez-Sanmartin M, Power DM, Herran-José F, Navas I, Batista FM (2016) Experimental infection of European flat oyster Ostrea edulis with Ostreid Herpesvirus 1 microvar: mortality, viral load and detection of viral transcripts by in situ hybridization. Virus Res 217: 55-62.

27. Arzul I, Renault T, Thébault A, Gérard A (2002) Detection of oyster herpesvirus DNA and proteins in asymptomatic Crassostrea gigas adults. Virus Res 84: 151-160. [Crossref]

28. Batista FM, Arzul I, Pepin JF, Ruano F, Friedman CS, et al. (2007) Detection of ostreid herpesvirus 1 DNA by PCR in bivalve molluscs: a critical review. J Virol Methods 139: 1-11.[Crossref]

29. Moss JA, Burreson EM, Cordes JF, Dungan CF, Brown GD, et al. (2007). Pathogens in Crassostrea ariakensis and other Asian oyster species: implications for non-native oyster introduction to Chesapeake Bay. Dis Aquat Org77: 207-223.

30. Martenot C, Oden E, Travaillé E, Malas JP, Houssin M (2011) Detection of different variants of Ostreid Herpesvirus 1 in the Pacific oyster, Crassostrea gigas between 2008 and 2010. Virus Res 160: 25-31.[Crossref]

31. Garcia C, Thébault A, Dégremont L, Arzul I, Miossec L, et al. (2011) Ostreid herpesvirus 1 detection and relationship with Crassostrea gigas spat mortality in France between 1998 and 2006. Vet Res 42: 73.[Crossref]

32. Prado-Alvarez M, Darmody G, Hutton S, O'Reilly A, Lynch SA, et al. (2016) Occurrence of OsHV-1 in Crassostrea gigas Cultured in Ireland during an Exceptionally Warm Summer. Selection of Less Susceptible Oysters. Front Physiol 7: 492.[Crossref]

33. Gittenberger A, Voorbergen-Laarman MA, Engelsma MY (2016) Ostreid herpesvirus OsHV-1 $\mu$ Var in Pacific oysters Crassostrea gigas (Thunberg 1793) of the Wadden Sea, a UNESCO world heritage site. J Fish Dis 39: 105-109.[Crossref]

34. Grijalva-Chon JM, Castro-Longoria R, Ramos-Paredes J, Enríquez-Espinoza TL, Mendoza-Cano F (2013) Detection of a new OsHV-1 DNA strain in the healthy Pacific oyster, Crassostrea gigas Thunberg, from the Gulf of California. J Fish Dis 36: 965968.[Crossref]

35. Grijalva-Chon JM, Castro-Longoria R, Ramos-Paredes J, Enríquez-Espinoza TL, Mendoza-Cano F (2013) Detection of a new OsHV-1 DNA strain in the healthy Pacific oyster, Crassostrea gigas Thunberg, from the Gulf of California. J Fish Dis 36: 965968.[Crossref]

36. Sauvage C, Pépin JF, Lapègue S, Boudry P, Renault T (2009) Ostreid herpes virus 1 infection in families of the Pacific oyster, Crassostrea gigas, during a summer mortality outbreak: Differences in viral DNA detection and quantification using real-time PCR. Virus Res 142:181-187.

37. Schikorski D, Faury N, Pepin JF, Saulnier D, Tourbiez D, et al. (2011) Experimental ostreid herpesvirus 1 infection of the Pacific oyster Crassostrea gigas: kinetics of virus DNA detection by q-PCR in seawater and in oyster samples. Virus Res 155: 28-34. [Crossref]

38. Arzul I, Nicolas JL, Davison AJ, Renault T (2001a) French scallops: a new host for ostreid herpesvirus-1. Virology 290: 342-349.[Crossref]

39. Renault T, Bouquet AL, Maurice JT, Lupo C, Blachier P (2014) Ostreid Herpesvirus 1 Infection among Pacific Oyster (Crassostrea gigas) Spat: Relevance of Water Temperature to Virus Replication and Circulation Prior to the Onset of Mortality. Appl Environ Microb 80: 5419-5426. 
40. Barbosa-Solomieu V, Miossec L, Vázquez-Juárez R, Ascencio-Valle F, Renault T (2004) Diagnosis of Ostreid herpesvirus 1 in fixed paraffin-embedded archival samples using PCR and in situ hybridisation. J Virol Meth1 19:65-72.

41. Farley CA, Banfield WG, Kasnic G Jr, Foster WS (1972) Oyster herpes-type virus. Science 178: 759-760.[Crossref]

42. Meyers TR, Burton T, Evans W, Starkey N (2009) Detection of viruses and virus-like particles in four species of wild and farmed bivalve molluscs in Alaska, U.S.A., from 1987 to 2009. Dis Aquat Organ 88: 1-12.[Crossref]

43. Arzul I, Renault T, Lipart C, Davison AJ (2001a) Evidence for interspecies transmission of oyster herpesvirus in marine bivalves. J Gen Virol 82: 865-870.[Crossref]

44. Renault T, Arzul I (2001c) Herpes-like virus infections in hatchery-reared bivalve larvae in Europe: specific viral DNA detection by PCR. J Fish Dis 24: 161-167.

45. Hine PM (2002) Significant diseases of molluscs in the Asia-Pacific region. In: Diseases in Asian Aquaculture IV. Lavilla-Pitogo CR, Cruz-Lacierda ER(Eds), Fish Health Section, Asian Fisheries Society, Manila pp: 187-196.

46. Hine PM, Wesney B, Besant P (1998) Replication of a herpes-like virus in larvae of the flat oyster Tiostrea chilensis at ambient temperatures. Dis Aquat Org 32:161-171.

47. Samain JF, Dégremont L, Soletchnik P, Haure J, Bédier E, et al. (2007) Genetically based resistance to summermortality in the Pacific oyster (Crassostrea gigas) and its relationship with physiological, immunological characteristics and infection processes. Aquaculture 268:227-243.

48. Normand J, Cornette F, Ledu C, Boudry P (2008) Study of the reproductive potential of triploid Pacific oysters 1 of triploid Pacific oysters (Crassostrea gigas, Thunberg). Poster section - Ifremer - Laboratoire de Génétique et Pathologie, Mus du Loup, France.

49. Normand J, Li R, Quillien V, Nicolas JL, Boudry P, et al. (2014) Contrasted survival under field or controlled conditions displays associations between mRNA levels of candidate genes and response to OsHV-1 infection in the Pacific oyster Crassostrea gigas. Mar Genomics 15: 95-102.[Crossref]

50. Dégremont L, Garcia C, Allen SK Jr (2015) Genetic improvement for disease resistance in oysters: A review. J Invertebr Pathol 131: 226-241.[Crossref]

51. Azéma P, Travers MA, Benabdelmouna A, Dégremont L (2016) Single or dua experimental infections with Vibrio aestuarianus and OsHV-1 in diploid and triploid Crassostrea gigas at the spat, juvenile and adult stages. J Invertebr Pathol 139: 92-101. [Crossref]

52. Azéma P, Lamy JB, Boudry P, Renault T, Travers MA, et al. (2017) Genetic parameters of resistance to Vibrio aestuarianus, and OsHV-1 infections in the Pacific oyster, Crassostrea gigas, at three different life stages. Genet Sel Evol 49: 23.[Crossref]

53. Allam B, Raftos D (2015) Immune responses to infectious diseases in bivalves. $J$ Invertebr Pathol 131: 121-136.[Crossref]
54. Green TJ, Vergnes A, Montagnani C, de Lorgeril J (2016) Distinct immune responses of juvenile and adult oysters (Crassostrea gigas) to viral and bacterial infections. $\mathrm{Vet}$ Res 47: 72.[Crossref]

55. Batista FM, Taris N, Boudry P, Renault T (2005) Detection of ostreid herpesvirus-1 (OsHV-1) by PCR using a rapid and simple method of DNA extraction from oyster larvae. Dis Aquat Organ 64: 1-4.[Crossref]

56. Dégremont L, Bedier E, Soletchnik P, Ropert M, Huvet A, et al. (2005) Relative importance of family, site, and field placement timing on survival, growth, and yield of hatchery-produced Pacific oyster spat (Crassostrea gigas). Aquaculture 249: 213-229.

57. Hine PM, Wesney B, Hay BE (1992) Herpesviruses associated with mortalities among hatchery-reared larval Pacific oysters Crassostrea gigas. Dis Aquat Org12:135-142.

58. Martenot C, Lethuillier O, Fourour S, Oden E, Trancart S, et al. (2015) Detection of undescribed ostreid herpesvirus 1 (OsHV-1) specimens from Pacific oyster, Crassostrea gigas. J Invertebr Pathol 132: 182-189.[Crossref]

59. Oden E, Martenot C, Berthaux M, Travaillé E, Malas JP, et al. (2011) Quantification of ostreid herpesvirus 1 (OsHV-1) in Crassostrea gigas by real-time PCR: Determination of a viral load threshold to prevent summer mortalities. Aquaculture 317:27-31

60. Peeler EJ, Reese RA, Cheslett DL, Geoghegan F, Power A, et al. (2012) Investigation of mortality in Pacific oysters associated with Ostreid herpesvirus-1 $\hat{\mathrm{I}}^{1 / 4} \mathrm{Var}$ in the Republic of Ireland in 2009. Prev Vet Med 105: 136-143.[Crossref]

61. Pepin JF, Riou A, Renault T (2008) Rapid and sensitive detection of ostreid herpesvirus 1 in oyster samples by real-time PCR. J Virol Methods 149: 269-276.[Crossref]

62. Pepin JF, Riou A, Renault T (2008) Rapid and sensitive detection of ostreid herpesvirus 1 in oyster samples by real-time PCR. J Virol Methods 149: 269-276.[Crossref]

63. Renault T, Arzul I, Lipart C (2004) Development and use of an internal standard for oyster herpesvirus 1 detection by PCR. J Virol Methods 121: 17-23.[Crossref]

64. Renault T, Moreau P, Faury N, Pepin J-F, Segarra A, et al. (2012) Analysis of Clinica Ostreid Herpesvirus 1 (Malacoherpesviridae) Specimens by Sequencing Ampli?ed Fragments from Three Virus Genome Areas. J Virolpp: 5942-5947.

65. Segarra A, Baillon L, Faury N, Tourbiez D, Renault T (2016) Detection and distribution of ostreid herpesvirus 1 in experimentally infected Pacific oyster spat. $J$ Invertebr Pathol 133: 59-65.[Crossref]

66. Segarra A, Mauduit F, Faury N, Trancart S, Dégremont L, et al. (2014) Dual transcriptomics of virus-host interactions: comparing two Pacific oyster families presenting contrasted susceptibility to ostreid herpesvirus 1. BMC Genomics 15: 580 [Crossref]

67. Vigneron V, Solliec G, Montanié H, Renault T (2004) Detection of Ostreid Herpesvirus 1 (OsHV-1) DNA in seawater by PCR: influence of water parameters in bioassays. Dis Aquat Organ 62: 35-44.[Crossref]

Copyright: (C2017 Mandas D. This is an open-access article distributed under the terms of the Creative Commons Attribution License, which permits unrestricted use, distribution, and reproduction in any medium, provided the original author and source are credited. 